\title{
A Puzzle about Obscenity
}

\author{
Michael Joel Kessler
}

\begin{abstract}
Laws against sexual obscenity rely on a distinction between explicit materials that merely offend and materials that cause something worse than offense. While most offensive content is protected under the banner of freedom of expression, obscenity is not. In this paper I try to locate a distinctive harm in the case of obscenity, that would justify prohibiting this material while permitting other kinds of offensive content. I argue that the best case for laws against obscenity relies on the concept of moral harm. If we rely on Mill's Harm Principle and moral harm is a real harm, then it could be used to justify the distinction between protected and unprotected sexually explicit speech. I argue this demonstrates a weakness in the Harm Principle as a liberal principle of justice. By giving weight to moral harm, Mill's principle risks eroding an important distinction between the public and private domains.
\end{abstract}

The right to freedom of expression protects a significant amount of offensive speech. This is regarded as the price we must pay to live in a society that values diversity of thought and political disagreement. Protecting offensive speech is so essential to the United States constitution that, unlike European and Canadian courts, the U.S. Supreme Court has consistently struck down hate speech laws aimed at protecting vulnerable groups from verbal abuse. The Court's rationale is that if the right to freedom of expression means anything then it must protect the worst speech as much as the best. ${ }^{1}$ By contrast, when it comes to sexually obscene expression the U.S. falls in line with many other countries in treating it as unprotected speech. Producers and distributors of such materials face fines or jail terms if convicted. ${ }^{2}$ Obscenity prosecutions have trended downwards in recent

\footnotetext{
${ }^{1}$ For examples, see National Socialist Party of America v. Village of Skokie 432 U.S. 43 (1977), R.A.V. v. ST. PAUL 505 U.S. 377 (1992), and Snyder v. Phelps 562 U.S. 443 (2011).

2 'Federal law makes it illegal to distribute, transport, sell, ship, mail, produce with intent to distribute or sell, or engage in a business of selling or transferring obscene matter. [...] Although the law generally does not criminalize the private possession of obscene matter, the act of receiving such matter could violate federal laws.' (Online at http://www.justice.gov/criminal/ceos/subjectareas/obscenity.html, last updated June 3 (2015) (accessed 2017-03-10).
} 
years yet these laws remain in place and there is little momentum to overturn them. ${ }^{3}$ During his election run in 2016 Donald Trump signed a pledge stating: 'Internet obscenity laws have not been aggressively or adequately enforced.' 4

The topic of sexual obscenity yields a division between liberal and conservative approaches to freedom of expression. Historically, liberals have regarded obscenity laws as an attempt to enforce puritanical moral standards on society as a whole, while conservatives argued that sexually explicit images can be corrupting to those who view them. Beneath the surface of this disagreement there is significant common ground. Both sides agree that some speech is not just offensive but rather can constitute an assault against its audience. In such cases there is no controversy about whether speech should be protected. Both sides agree that the state has an important role to play in balancing free speech rights against shielding citizens from being harmed. So why is the legal status of sexual obscenity controversial?

The reason for the split surrounds the idea of harm. Laws against sexual obscenity rely on a distinction between sexually explicit materials that merely offend on the one hand, and materials that cause something worse than and different from offense on the other. Proponents of censorship argue that obscene materials harm rather than offend, and this is what justifies a legal intervention. This is not what the other side denies. Rather, opponents of obscenity law deny that the harms in question are sufficient to overturn the right to freedom of expression. Hence, the real point of contention surrounds the precise nature of the harms in question, and whether they are weighty enough to infringe upon a basic right.

A focused debate about the relative political weight of different kinds of harm rarely emerges because there is a tendency to group very disparate harms under one category. This conflation is pervasive in political discourse. In a 2011 letter addressed to President Obama's Attorney General, forty-one Senators said:

We know more than ever how illegal adult obscenity contributes to violence against women, addiction, harm to children, and sex trafficking. This material harms individuals, families and communities and the problems are only getting worse. ${ }^{5}$

The letter appeals to several different kinds of harm, most of which are conceptually and practically distinct. The same point can be seen in the United Kingdom's recent attempts to modernize its obscenity laws. The new charge of 'possession of extreme pornography' prohibits accessing images that are 'grossly offensive, disgusting or otherwise of an obscene character, ${ }^{\prime}{ }^{6}$ where obscene character refers to materials that 'tend to deprave and

\footnotetext{
3 In 2005, under President George W. Bush, the U.S. Department of Justice created the Obscenity Prosecution Task Force (OPTF). In 2011, under President Barack Obama, this unit was folded into the Child Exploitation and Obscenity Section (CEOS). Republicans criticized this change as indicative of the administration's lack of commitment to prosecuting producers of hardcore pornography.

4 The Children's Internet Safety Presidential Pledge. Online at http://enough.org/objects/EIEprespledge-signedtrump.pdf (accessed 2017-03-10).

5 The letter is reproduced at http://www.politico.com/static/PPM153_obsc.html (accessed 201605-08).

${ }^{6}$ Criminal Justice and Immigration Act s.63(6)(b).
} 
corrupt persons. ${ }^{\prime 7}$ Disgust, depravity, and corruption are distinct concerns and do not rise and fall together. As such, when the government says the law sends 'a clear message that it has no place in our society' it is not clear what 'it' is, and why we should not allow reasonable pluralism with respect to its value as we do with most expression. 8 In Canada, obscenity law restricts 'undue exploitation of sex' which isolates materials that are either violent, or dehumanizing, or degrading. The Court's concern is with pornography that serves 'to reinforce male-female stereotypes to the detriment of both sexes' or that makes 'degradation, humiliation, victimization, and violence in human relationships appear normal and acceptable.' 9 Any such materials will be found obscene if they violate a community standard of tolerance for what people should be allowed to consume in private.

In all three countries obscenity law identifies a sub-group of pornography, made by and for consenting adults, and holds it to a higher legal standard than other materials. In each case there is a lack of precision about what specifically makes obscene pornography bad. This is a different problem from the definitional difficulties associated with a 'you know it when you see it' standard..$^{10}$ The problem here is the lack of clarity about what one is supposed to be looking for.

This jumbled legal approach to obscenity reinforces the complaint that at its root this is just sexual conservatism. In this paper I will argue that the case for obscenity law is strongest when we understand it as a concern about moral harm to consumers of obscene pornography. There are a variety of ways of understanding what it means to be morally harmed, and all share the general idea that one is made into a worse person than one was before. The liberal camp has mostly dismissed moral harm as shorthand for outmoded views about sex, but this response is mistaken. I will show that there is a plausible argument connecting obscene pornography with moral harms to willing consumers by interfering with their ability to function within society. If moral harm is a genuine category of harm then liberals owe an argument for why the law cannot be used to shield individuals from it. This is a task few have taken up with much depth.

I will take as my ethical starting point a broadly Millian form of liberalism that places foundational value on the independence of the individual within society. Mill argues that within a democracy those with unconventional preferences should not have to 'request permission to differ' from others. ${ }^{11}$ This violates both the equality of persons and the important liberty that each person needs to test out for oneself which ways of life are best. For this reason Mill defends a right to liberty of tastes and pursuits alongside his famous arguments for freedom of expression. This implies that individual freedom, especially when it comes to both unpopular choices and unpopular speech, must be

\footnotetext{
7 Obscene Publication Act s.1.

8 Home Office 2005, 1. Cited in Paul Johnson 'Law, Morality and Disgust: The Regulation of “Extreme Pornography” in England and Wales', Social \& Legal Studies 19:2 (2010), pp. 147-163.

${ }^{9}$ Regina v. Butler, 1 S.C.R. 452 (1992).

10 Jacobellis v. Ohio, 378 U.S. 184 (1964). Few people who cite Justice Potter's words recall the ones that preceded them: 'I shall not today attempt further to define the kinds of material I understand to be embraced within that shorthand description; and perhaps I could never succeed in intelligibly doing so.'

11 John Stuart Mill, On Liberty (1859), edited by Mary Warnock (Oxford: Blackwell: 2003), p. 93.
} 
protected from society's tendency to 'compel people to conform to its notions of personal as of social excellence.' 12

Beyond his arguments about fundamental rights, Mill has much to say about how people should behave towards each other in public, how husbands should treat their wives within the home, and how society should promote human flourishing. This leads to a debate among Mill scholars about what his views would be about pornography. Pro-censorship interpreters argue that commercial pornography negatively affects women which conflicts with Mill's vision of 'perfect equality'13 between the sexes. Anti-censorship interpreters argue that Mill's concern with the dangers of giving legal force to the 'tyranny of the prevailing opinion and feeling'14 would take precedence over the very important goal of eliminating the social bases of gender inequality. ${ }^{15}$

My goal is not to offer a textually exhaustive argument to convince the procensorship Millians they are wrong. Nor is it to vindicate a definitive no-censorship reading of Mill's writings. My aim is to show that, in cases that do not involve the causation or incitement of direct harms, the anti-coercion aspect of Mill's principles places a high burden of proof on the use of the law to regulate individual conduct. On the basis of this ethical theory I will argue that the distinction presupposed by obscenity law, namely that some but not all consensually made pornography contains a distinctive harm, cannot be justified. ${ }^{16}$ Accordingly, the argument that pornography merely offends while obscenity harms does not succeed. Therefore, if pornography is protected expression then so is obscene pornography.

The paper proceeds as follows. First, I will outline some basic Millian principles. Second, I show how American courts have given conflicting rulings on pornography. One way to resolve the conflict is to suppose, as courts implicitly have, that there is some distinctive harm contained in obscene pornography that is missing from the rest. Third, I will argue that the best way to understand this distinctive harm is moral harm. I show that on a view of moral harm that both liberals and conservatives care about, there are theoretical and empirical reasons against using moral harm as a basis for selective restriction within the category of pornography. Fourth, I show why moral harm is a problematic concept to countenance as the basis for law when fundamental rights are at issue. I conclude that the best way to regulate the worst kind of pornography is by

12 Ibid., p. 97.

13 John Stuart Mill, 'On the Subjugation of Women' (1869), in On Liberty and Subjection of Women, edited by Alan Ryan (London: Penguin Classics, 2006), p. 133. See also David Dyzenhaus 'John Stuart Mill and the Harm of Pornography' Ethics 102:3 (1992), pp. 534-551 and Clare McGlynn and Ian Ward, 'Would John Stuart Mill have Regulated Pornography?', Journal Of Law And Society, 41:4 (2014), pp. 500-522.

14 Mill, On Liberty, p. 91.

15 See for example Nick Cowan, 'Millian Liberalism and Extreme Pornography', American Journal of Political Science 60:2 (2016), pp. 509-520.

16 For the purposes of this paper I am restricting the subject matter to pornography that does not include actual corpses, animals, children, or rape. In each of these cases there can be no valid consent by at least one of the parties depicted. Further, these acts are already criminal in most jurisdictions, so they would enjoy no protection qua expression. There is an extremely difficult question about whether to criminalize pornography that simulates sex with animals, corpses, children, and unwilling women. I do not address that issue fully here, though my conclusion is compatible with permitting personal use but banning distribution. 
abandoning the legal concept of obscenity altogether. My argument is compatible with the regulation of all pornography based on egalitarian considerations. However in order to do so one must reframe the debate away from rights-based arguments about freedom of expression.

\section{Millian Principles}

Mill famously sought to establish a principle for determining 'where to place the limit [...] between individual liberty and social control?'17 This seems like exactly the right question for present purposes. ${ }^{18}$ Laws against sexual obscenity are a form of social control in a direct way since they block people from acquiring materials of interest to them. This also has a limiting effect beyond willing consumers and producers. The law protects unwilling audiences from exposure to these materials, and in so doing also prevents potential consumers who have no current view on these materials from discovering them.

This is a general point about legal prohibitions on purchases but it also has a special connection to Mill's account of freedom of expression. Whenever a government regulates expressive content - what can be said or published - the community as a whole is deprived of something whether they realize it or not. Even if you never had any intention of buying obscene materials, the fact that they are banned affects you. When ideas are present in the marketplace then people can respond to them, positively or negatively. When those ideas are banned from the marketplace there is nothing for anyone to respond to, favourably or otherwise.

It is important not to overstate this point. All we have noted so far is that banning expression changes the 'marketplace of ideas' by making it harder for certain ideas to compete. This can in principle yield good or bad results, and it is precisely this question the state must assess by considering the likely effects of making certain expression illegal because of its content. In chapter II of On Liberty Mill draws our attention to the dangers of entrusting the state with the power to censor what it considers to be bad ideas. Governments could use this authority to silence ideas contrary to their political interests. This abuse of authority has a well-established history. However Mill's worry about social control includes more than just power hungry dictators.

As Mill puts it 'all restraint, quâ restraint, is an evil.'19 A law against obscenity might be overwhelmingly popular, however such a law involves a restriction on the freedom of those who would like to produce, sell, and buy obscene materials. Society may not see much value in these choices, but that does not make the legal prohibition costless. From the standpoint of those constrained there is a significant loss of freedom, that is for them an 'evil'. This constraint needs to be justified. As citizens we are owed an

17 Mill, On Liberty, p. 91.

18 This is one among many possible theories of political morality. Some will reject Mill's claim that harm is the only criterion for law. Even if one disagrees with Mill, any plausible theory will agree that to be harmed is bad, and that in some cases it is the proper role of the law to protect us from being harmed.

${ }^{19}$ Mill, On Liberty, p. 165. 
explanation whenever majorities, though the legislature, impose legal limits on individual choice.

What this means is that even if we could show that the marketplace of ideas would not suffer as a result of censorship, this would not justify the interference. Censorship is contrary to an interest that Mill regarded as fundamentally related to freedom, namely the ability to make one's mind up rather than being told what to think. ${ }^{20}$ When I am forbidden from encountering certain ideas then I am less able to reason critically about them. If the government suppresses offensive content then it also interferes with the audience's interest in reaching conclusions on their own, even if the audience would (or should) eventually come to reject those ideas. This is why restraint is an evil - it is contrary to freedom of the mind.21 As a matter of political and moral principle, it is better for an idea to be heard and repudiated than for it to be silenced.

This principle is not absolute. Mill very clearly endorses the conclusion that censorship can sometimes prevent harm, and should be employed in those cases. Mill gives the example of preventing someone from inciting a riot by restricting his speech to an enraged mob.22 The question before us is how to weigh the prevention of the harms from the riot against the harms inherent with empowering the state to interfere with the free exchange of ideas? To answer this we need to return to the Harm Principle, which states:

[...] the only purpose for which power can be rightfully exercised over an member of a civilized community, against his will, is to prevent harm to others. His own good, either physical or moral, is not a sufficient warrant. Over himself, over his own body and mind, the individual is sovereign. ${ }^{23}$

There are two distinct parts to Mill's principle: (1) it is wrong to coerce people through the criminal law unless they are harming others, and (2) it is not the proper role of the law to improve a person's character.

The first part identifies the criterion by which we determine whether coercion can be considered at all. Harm to another must be present or very close at hand. Any attempt to use the law to restrain individual choice is immediately under an evidentiary burden to show proof of harm to others. The harm-to-others condition is met by Mill's example of inciting the enraged mob by blaming their poor circumstances on the corn dealers. As he explains, these very same words could be published in a newspaper without censorship. The difference is that when speaking to the mob, the speech act and severe physical harm to specific others are tightly causally linked. By contrast, if a person reads a column stating the same opinion and then attacks the corn dealer, the agent has become the main cause of the harm. The mediating steps taken by this agent - reading, thinking, arming oneself, setting off with intent to injure - push the newspaper column very far away from the eventual assault. Therefore, unless one's speech leads to a direct, immediate, and severe harm to another there can be no justification for censorship.

\footnotetext{
${ }^{20}$ Ibid., pp. 114-118.

21 David Brink, 'Millian Principles, Freedom Of Expression, And Hate Speech', Legal Theory 7 (2001), pp. 119-157.

22 Mill, On Liberty, p. 131.

${ }^{23}$ Ibid., pp. 94-95, emphasis added.
} 
The second part of the Harm Principle - sovereignty over one's mind and body identifies a criterion that cannot justify law. Mill recognizes that the law could be very effective in making us into better people, and thereby improving the quality of the society we share. However, this form of reasoning about legal coercion is blocked. Each of us is responsible for improving our characters, which means that no one can be compelled to take up that responsibility. If I choose not to become a better version of myself the state may not force me to improve because, over myself, over my own body and mind, I am sovereign.

As applied to the domain of expression, Mill would readily grant that exposure to certain messages can harm the audience. However, if this exposure is willing then it counts as a risky choice and these fall squarely within the realm of individual sovereignty. When discussing cases of harms-to-self Mill consistently adheres to the principle that society has a duty to warn people of the dangers they face, but to leave individuals as much as possible in control of the ultimate decision. The clearest example of this is when considering a man walking across a faulty bridge, Mill states that if 'there were no time to warn him' then we may forcibly interfere without wronging him. If there is time, however, then the person ought 'to be only warned of the danger; not forcibly prevented from exposing himself to it.' 24

This provides clear ethical guidance for purely private choice. Mill acknowledges that self-harms may not always be sequestered to the life of individual. He cites the example of private drunkenness to make the point. If my drinking affects my driving then clearly the danger is no longer just to myself. No one may choose to add danger to the life of another with securing consent. Invading your sovereignty cannot be part of my sovereignty. ${ }^{25}$

Putting the two parts together, Mill's general moral view is that the law must be used to protect us from harms imposed on us by other people. Assaults, whether verbal or physical are prohibited, as are incitements to commit assaults. This means that actions that harm others are a matter of public concern and invoke the coercive powers of the law. The law cannot, however, be used to protect us from our own bad selves. Actions whose immediate harms befall only the agent must remain legal and be kept beyond the scope of the law, so long as that harm is knowingly and willingly accepted. Self-harms

24 Ibid., p. 165.

25 Ibid., p. 166. In 'Would John Stuart Mill have Regulated Pornography?', McGlynn and Ward argue this shows that self-harms can be harms-to-others at the same time. 'The very fact of being drunk constitutes the harm to others, even in the absence of proof of a crime being committed, due to the risk of further crimes of violence. [...] This precautionary approach was summed up by Mill elsewhere when he stated that: 'It is the business of the law to prevent wrongdoing, and not simply to patch up the consequences of it when it has been committed.' (p. 507) I disagree with this reading of the text. Mill defends pre-emptive action with those who have been convicted of previous offenses involving drunkenness. We know in their case that alcohol leads to violence. This argument does not generalize to those who have not committed crimes. As Mill states: 'I should deem it perfectly legitimate that a person, who had once been convicted of any act of violence to others under the influence of drink, should be placed under a special legal restriction, personal to himself.' (On Liberty, p. 166) For similar reasons I disagree with Brecher's interpretation of regulation as proof that 'Mill [...] subordinates individual autonomy more than many liberals would accept.' (Bob Brecher, Getting What You Want? A Critique of Liberal Morality (London: Routledge, 1998), p. 166) I regard restrictions as opposed to prohibitions as Mill's attempt to balance risk of harm to others with individual liberty. 
'cannot without tyranny be made a subject of legal punishment' unless 'a man fails to perform his legal duties to others. ${ }^{26}$ As applied to the domain of expression, both harms to self and harms to others are to be tolerated as a consequence of protecting freedom of the mind. Toleration extends up to the point where the speech itself constitutes an assault.

\section{A Puzzle about Obscenity}

American jurisprudence embodies some of the points Mill defends in On Liberty as well as the thesis that there is a substantive difference between the offensiveness of pornography and the harm of obscenity. When we look at the case history concerning sexually explicit expression, we can see very clearly that the law is trying to target a specific kind of harm that lives in obscene pornography and only in obscene pornography. ${ }^{27}$

Laws against obscenity are a species within a general category of laws regulating wounding words. ${ }^{28}$ Over the last fifty years the U.S. Supreme Court has settled on a twolevel theory with respect to laws constraining freedom of expression. The first level refers to Content-Neutral (CN) Restrictions. A restriction on expression is content-neutral when it involves no direct reference to the message being expressed. Since no specific message is picked out as bad, CN-restrictions do not raise worries about censorship directly. ${ }^{29}$ The second level involves Content-Based (CB) Restrictions. Here the state identifies some particular message as inappropriate and uses the law to ban it. Given the high likelihood that such laws could be used to suppress competing political views or to marginalize minorities, CB-restrictions must pass a much more stringent standard of review. ${ }^{30}$ Courts have established that when the government tries to restrict expression in a contentspecific manner, it must show that the damage that is done to free speech could only be avoided by allowing something worse to happen. This mirrors the logic of Mill's

26 Mill, On Liberty, p. 166.

27 This is the spirit of both English and Canadian obscenity laws as well, though both countries are trying to move towards an evidentiary standard of harm for all pornography. Canada's Supreme Court ruling on indecency points to the end of using community standards altogether. See Richard Jochelson, 'After Labaye: The Harm Test Of Obscenity, The New Judicial Vacuum, And The Relevance Of Familiar Voices, Alberta Law Review. 46:3 (2009), pp. 741-767. For a discussion of the U.K.'s failure to move completely to an evidence based standard of harm, see Clare McGlynn and Erica Rackley,'Criminalising Extreme Pornography: A Lost Opportunity', Criminal Law Review 4 (2009), pp. 245-260.

28 I will focus on the American context here. For a thorough analysis of the Canadian approach to obscenity see Leonard W. Sumner's The Hateful $\mathcal{E}$ The Obscene (Toronto: University of Toronto Press, 2004). For a comparison between the Canadian and American contexts see Bret Boyce, 'Obscenity and Community Standards', Yale Journal of International Law 33 (2008), pp. 299-513, see especially pp. 322-338..

29 Content-neutral restrictions do raise indirect worries. A restriction on protesting, for example, can be content-neutral yet mostly penalize the side of the debate that struggles to get its message out via other means.

30 Justification for content-based censorship was for a long time subject to the 'clear and present danger' test. This test has been since refined so as to only apply when speech intends to incite or produce 'imminent lawless action'. See Brandenburg v. Ohio 395 U.S. 444 (1969). 
exemption for speech that incites a riot. Restraint is an evil, but in such cases it is a necessary evil.

Obscenity does not fit anywhere on the two-level view. The Court draws a separate distinction between 'high' and 'low' value expression. Obscenity falls into the low-value category, alongside fraud, ${ }^{31}$ defamation, ${ }^{32}$ and incitement to law breaking. ${ }^{33}$ High value speech enjoys a very strong presumption against content-based censorship, and can only be restricted in accordance with a stringent standard of review. Low-value speech can be restricted precisely because of its content, and therefore enjoys no strong protection.

From a Millian perspective you can see the logic of the distinction between high and low value speech. Fraud and defamation are speech acts that clearly impose direct harms on identifiable others: I take your money or your reputation from you without your consent. Banning this kind of expression prevents a direct harm in the same way that a law against robbery prevents direct harm. It is true that banning defamation involves content regulation, but this presents no special problem because the content of the expression is the cause of the harm. There is no reason to protect harmful acts just because they involve speech rather than force. As we have seen with Mill's example of inciting a riot, speech-based harms can be prohibited under the Harm Principle when there is a direct connection between the speech and a significant harm to assignable individuals.

This does not yet explain why obscenity is lumped in with fraud and defamation. On the American model, non-obscene pornography, non-sexual gory imagery involving corpses, and hate speech are considered high value and protected from censorship. Obscenity is not protected. What is it about obscene sexual expression that makes it low value? In looking at the case history we can see that courts have fumbled around with this question while steadfastly affirming obscenity's low value status. I'll briefly mention two cases that bring out what I see as the puzzle of obscenity.

Consider first Rowan v. US Post Office Department. ${ }^{34}$ In the world before the Internet, people selling sexually explicit materials would reach out to potential customers by mailing catalogues advertising available titles and genres. Unsurprisingly, many homeowners were upset to receive these mailings. The Court ruled that the individual householder has an 'absolute and irrevocable' right to determine whether such mailings could be delivered in the future. ${ }^{35}$ With this decision the Court established a defeasible permission on direct mailings of a sexual nature. The rule is the following: pornographers are allowed to mail these materials until the homeowner complains. The determination of which sexual materials are offensive is entirely subject to the homeowner's judgment. So, a homeowner who does not object to receiving catalogues from Playboy retains the right to object to solicitation from more hardcore magazines.

I will refer to this as an Opt-out Model. According to this model, the best policy is one that allows individuals to judge what is offensive from their own point of view. Once

\footnotetext{
31 See Va. State Bd. of Pharmacy v. Va. Citizens Consumer Council, Inc. 425 U.S. 748 (1976).

32 See NY Times Co. v. Sullivan, 376 U.S. 254 (1964).

33 See Brandenburg for incitement criteria.

34397 U.S. 728 (1970).

35 Ibid., p. 757.
} 
this is positively established, any future solicitation is actionable. ${ }^{36}$ The appeal of Opt-out is that the government takes no stand on whether these materials are in fact offensive. Rather, the law's role is merely to enforce the right of the individual against unwanted exposure. By deferring to the judgment of the homeowner, the state sidesteps the issue of content regulation. ${ }^{37}$

Under an Opt-out model the advertiser remains free to address other people who might want to become customers. So, the loss of freedom is minimal since the seller is still able to reach the desired audience. The restriction is that the seller must to cast the net more cautiously so as to exclude the unwilling. So, even though Rowan picks out some content - sexual materials - as subject to regulation, Opt-out maintains viewpoint neutrality. It is the homeowner, not the government, who decides which content to restrict. Rowan thus embodies most of the core values of Mill's approach to restricting speech. In Mill's framework, there is always an 'evil' wherever the law is used to constrain free choices and Rowan effectively constrains that evil in a way that is sensitive to all the interests at stake.

The second decision germane to our discussion is the Court's landmark obscenity ruling in Miller $v$. California. The 1973 ruling established that material is criminally obscene based on whether

(a) the average person, applying contemporary community standards would find that the work, taken as a whole, appeals to the prurient interest; (b) whether the work depicts or describes, in a patently offensive way, sexual conduct specifically defined by the applicable state law; and (c) whether the work, taken as a whole, lacks serious literary, artistic, political, or scientific value. 38

The striking thing about Miller is that it endorses a very different approach to the sale of sexually explicit material. I am going to describe Miller's underlying principle as the Democratic Model. On this model, the best policy is one that allows juries to determine which explicit materials should be banned. Like Rowan, Miller is a subject-matter restriction, since the materials must appeal to a prurient interest in sex, as opposed to a prurient interest in violence or money. ${ }^{39}$ Miller picks out a special kind of intention - the desire to arouse - as a necessary condition for sexual material to be obscene. This exempts content that is sexual in nature but has educational or medical value from being deemed obscene. The third condition - overall merit - is meant to protect sexually explicit literary works from being banned. However, a literary work that goes too far in its prurience can still be found obscene if the offense it causes, judged by community standards, is not redeemed by its overall artistic value.

36 An opt-out model can be narrow or broad. In addition opt-out models can be preemptive or after the fact. Compare for example national and local 'do not call' lists versus legislation requiring email advertisements to honour 'unsubscribe' requests.

37 Rowan was written to apply only to sexually explicit materials. There is a question about whether it would apply if one objected to receiving other mailings. The case law since Rowan has not resolved this ambiguity.

38 Miller v. California, 413 U.S. 15, 24 (1973)

39 See Geoffrey R. Stone, 'Restrictions of Speech Because of its Content: The Peculiar Case of Subject-Matter restrictions', The University of Chicago Law Review 46:1 (1978), pp. 81-115. 
Both rulings say there is something special about pornography that calls for intervention in the market. ${ }^{40}$ The key differences are, first, that Rowan says individuals can decide for themselves whether to welcome solicitations of prurience from sellers of sexual materials. Miller deviates from Rowan by saying that there are some sexual materials no one should be able to see, and that this judgment is to be made on a case-bycase basis by a jury of one's local peers. Second, Miller jettisons viewpoint neutrality entirely, since a buyer of obscenity cannot sway the prosecutor by saying 'it's not offensive to me.' A homeowner can do precisely that under Rowan, by refraining from opting out when he receives dirty catalogues in the mail. A third key difference is that Miller criminalizes the production and sale of something that some citizens enjoy and seek out. Rowan stays out of the marketplace entirely, except to enforce individual sovereignty over wanted and unwanted solicitation.

A finding of obscenity establishes that some expression does not deserve to be heard even by willing audiences. This kind of censorship is usually held to the very high standard that the speech will or is likely to cause imminent violent lawlessness. But Miller makes no claim that banning private voluntary exposure to obscene materials is thwarting any such harm. Miller declares that this standard does not apply, since the speech is low-value.

The puzzle of obscenity now emerges. What explains the difference between the treatment of direct sexual mailings from Rowan to Miller? Why shift from an individualcentered model (Opt-out) where the government takes no stand on what is offensive and avoids the issue of censorship, to a community-centered model (Democratic) where the government, via the courts, declares some ideas to be criminally offensive? Why opt for censorship when a more neutral and less restrictive option is already in place?

The rulings look contradictory. One way to dissolve the contradiction is the following: the standards for obscenity are different than the standards for pornography. So despite their surface similarities, these rulings apply to different domains. Rowan applies to the merely pornographic, which may or may not be offensive. By contrast, Miller applies to what lies beyond offense. Therefore the rulings are not in tension with each other.

If this analysis is correct, in Miller the Court affirmed a genuine content-based difference between pornography and obscenity. Canadian and English courts have drawn the same distinction though not as clearly. All agree that obscenity is what lies beyond offense, and all agree that obscenity can be identified by looking at the effects of this content on its audience. I now turn to the question of what that effect could be, and whether a Millian view could justify criminalizing some kinds of pornography on this basis.

\footnotetext{
40 This justification for content regulation can be criticized on its own merits. What is it about sexual materials that makes them different from violent or politically charged materials? For the purposes of the argument I'll leave this aside. My focus is on the differences between Rowan and Miller so, as with the previous footnote, I'll assume that the subject-matter restriction to sexual materials is permissible.
} 


\section{A Millian Case for Obscenity Law}

There are two levels to thinking about obscenity within a Millian framework. The first is whether or not there is distinctive harm lurking in obscene sexual expression. This would provide a basis for drawing distinctions within the category of offensive sexual expression. If we can identify the distinctive harm associated with obscene pornography, the second level is to determine whether the presence of this distinctive harm justifies removing this type of consensually made pornography from the marketplace.

Let's clarify two assumptions we are taking on board, one from Mill and one from the case history. First, there must be some domain of privacy. According to the Harm Principle an action is private when its consequences do not harm anyone but the agent. Absent some evidence that the harm extends beyond the agent, such choices must be permitted, though the state has a duty to warn the agent of the inherent danger. Second, the state may not rule that all sexually explicit material is obscene. In order for Miller and Rowan not to be flatly contradictory, there must be both protected and unprotected pornography. To declare all pornography as obscene (and therefore lowvalue) would imply that individuals would not be free to consume any sexually explicit materials in private. This is not what Miller says, nor what it intended. The ruling was narrowly crafted with the goal of leaving most pornography firmly in the domain of protected expression. Thus, to show that obscenity law is both philosophically and legally sound we need to show that some but not all pornography generates harms that extend beyond the realm of personal sovereignty even when used in private. These special harms are what justify treating obscenity, but not pornography, as a public matter subject to legal coercion.

I will consider two kinds of arguments that attempt to meet this challenge: (1) Social Harm arguments, and (2) Moral Harm arguments.

\section{Social Harm}

Consider the following very plausible claim: the community is made worse off by obscene materials, even when those materials are consumed in private. If we can show this, then the difference between pornography and obscenity is that the latter produces tangible social harms while the former does not. If these harms are sufficiently widespread it is compatible with Millian principles for this to overturn the presumption in favour of individual liberty.

How would private consumption of obscene materials harm society in way that is not also present in the case of run-of-the-mill pornography? I'll consider three versions of this argument. First, we can focus on the harms to unwilling audiences. This is a sound strategy: we want to protect the unwilling from being harmed by the decisions of the willing. There is something shocking about being exposed to graphic sexual content. The Harm Principle can certainly countenance psychological damage due to unwilling exposure as a real and significant harm. ${ }^{41}$ This is exactly the logic of the Rowan ruling: no

41 In 2011 France expanded their protections against spousal abuse to include a ban on actions that involve mental cruelty. These actions are classified as psychological violence. See http://www.theglobeandmail.com/news/world/france-still-struggling-with-its-landmarkspousal-mental-cruelty-law/article4252503/ (accessed 2016-07-25). 
one should be subjected to unwanted exposure just because other people want to sell and buy graphic content. ${ }^{42}$

However, if that's the extent of the social harm then the correct solution is much less restrictive than the criminal ban imposed by Miller. Restrictions on where obscene materials can be bought, sold, and displayed will successfully protect unwilling audiences. We have established methods for preventing unwanted exposure including warning labels, check-boxes before entering websites, consent forms, zoning laws, and ISP-based blocks. Why would we insist on different standards for obscene materials than the ones that work reasonably well for pornographic materials? If a shop has an 'adults only' sign on it, what difference would it make if this store specializes in obscene pornography rather than softer options? The bystander and the consumer have both been adequately warned that danger lies ahead. According to Mill, this is where legal interference should end.

A defense of Miller based on the social harm of unwanted exposure fails to justify a criminal ban rather than regulation. ${ }^{43}$ Regulation can manage the risk of unwanted exposure to all kinds of offensive expression without resorting to censorship and criminal penalties for possession, as is now the case in the U.K. ${ }^{44}$

There is a second sense of social harm that makes more progress towards distinguishing obscenity from pornography. One could argue that the willing consumers of obscenity threaten the physical security of others. On this hypothesis, viewing obscene materials can make you into a criminally dangerous person, or at least creates a high risk of this happening in some viewers. As with Mill's example of inciting a riot by feeding inflammatory words to a charged audience, perhaps obscene pornography incites people to commit acts of sexual violence they would otherwise not commit. This would connect the private act of viewing the materials with the very public act of criminal violence.

The idea that obscenity inspires violence has been a part of the discussion of obscenity for decades. Canadian and American courts found it 'reasonable to presume' that such a causal relationship exists even if evidence is hard to find..$^{45}$ English courts endorsed this as well, stating:

The Government believes there is some evidence that viewing these images may have an effect on young peoples' attitudes to sexual and violent behaviour, and that that some men can exhibit heightened aggression towards women after exposure to violent pornography. 46

42 This shows that we do not need to adopt what Dyzenhaus calls a 'narrow harm principle' where only direct physical assault count as proscribed acts. See Dyzenhaus, 'John Stuart Mill and the Harm of Pornography', p. 544.

43 This reply omits reference to the value of unwanted exposure. While we want to protect people from shock we don't want to do it in a way that prevents people from challenging conventional ideas. For a discussion of the reasons for allowing unwanted exposure, see T.M. Scanlon, 'Freedom of Expression and Categories of Expression', University of Pittsburgh Law Review 40 (1978-1979).

44 See Clare McGlynn and Erica Rackley, 'Prosecuting the Possession of Extreme Pornography: A Misunderstood and Misused Law', Criminal Law Review 4 (2013), pp. 400-405.

45 See Boyce, 'Obscenity and Community Standards', p. 332.

${ }^{46}$ Criminal Justice and Courts Bill, Section 10. 
This version of the social harm strategy face the challenge that the empirical case connecting viewing obscene pornography causes direct criminal violence is inconclusive. ${ }^{47}$ Unlike Mill's example of setting off a charged mob with invective, clear causation between a specific type of pornography and acts of violence is rare. ${ }^{48}$ Where there is a link, the U.K. the government's research concluded: 'The findings of the metaanalyses indicated an increased susceptibility to the influence of pornographic material on men who are measured as having a combination of high predisposing aggression levels, past histories of sexual and other aggression, self-reported likelihood to rape and sexual arousal to rape depictions.' 49 This evidence supports a plainly Millian solution: when someone shows themselves unfit to safely use some dangerous material we are permitted to restrict that person's access to it in the name of preventing direct harm to others.

The justification for this restriction on the browsing habits of offenders does not generalize to non-offenders. The overwhelming majority of pornography users of all types never commit crimes and that is the kind of social harm we are now focusing on. Since the acts of violence in question are already criminal, single cases of inspiration will not be sufficient to justify further legislation banning swaths of pornography that many use regularly and safely.

More detailed work needs to be done in this domain to test whether specific kinds of pornography have greater tendencies to produce acts of violence in individuals without 'high predisposing aggression levels'. Even if such evidence can be produced reliably under testing conditions, we would need to weigh this evidence against the evidence that availability of this pornography functions as a safety-valve for individuals with violent predispositions. ${ }^{50}$ Moving from Mill to Miller, the fact that someone might use obscene pornography as criminal inspiration does not present a threat of 'widespread imminent lawlessness.' Under American law, this is what needs to be shown to justify banning protected speech. This is why starting riots can be banned. There are very specific physical harms associated with the expression in a specific context. Pointing to

47 Sumner canvasses the social scientific literature on this issue. See Sumner, The Hateful $\mathcal{E}$ The Obscene, pp. 131-141. While there is some correlation between exposure to violent materials and violent attitudes towards women, this is not limited to the domain of sexually violent materials. As such, Miller's claim that violence must be coupled with sex to count as obscene lacks an evidentiary basis.

48 In the decade since Sumner's survey, further studies have aligned with his analysis. For a review of the recent empirical literature, see Milton Diamond's 'Pornography, Public Acceptance and Sex Related Crime: A Review', International Journal of Law and Psychiatry 32 (2009), pp.304-314: 'Indeed, the data reported and reviewed suggests that the thesis [that pornography increases violence] is myth and, if anything, there is an inverse causal relationship between an increase in pornography and sex crimes.' (p. 312)

49 Catherine Itzin, Ann R. Taket and Liz Kelly, The evidence of harm to adults relating to exposure to extreme pornographic material: a rapid evidence assessment. Ministry of Justice research series, 11/07 (London: Ministry of Justice, 2007).

50 See Andrew Koppelman's discussion of the safety valve rejoinder to fantasy depictions of sexual violence in 'Does Obscenity Cause Moral Harm?', Columbia Law Review 105:5 (2005), pp. 1635-1679, at pp.1658-1659. See also a summary of this evidence in 'The Sunny Side of Smut' in Scientific American; online at https://www.scientificamerican.com/article/the-sunny-side-of-smut/ (accessed 2017-03-10). 
cases where pornography has inspired sexual violence will not be sufficient to clear the high standard for banning expression based on its content.

Finally, and perhaps most importantly for the purposes of my argument, correlations can be observed between content consumption and increased aggression in the case of both violent and non-violent pornography. ${ }^{51}$ Correlations can also be found with non-sexual video games, graphic novels, or movies.52 All of these are subject to regulation like age-restrictions rather than being treated as low-value criminal expression. Since Miller is narrowly drawn to apply only to crude depictions of sex, any evidence that quickly generalizes to other content fails to locate a specific harm inherent only in sexual obscenity that would explain why it stands legally apart from the rest of expression that is correlated with inducing aggression.

The violence version of the social harm argument is not very persuasive on empirical grounds. The evidence fails to validate the content-based censorship we see in Miller. A third version of the social harm argument focuses on the specific harms of pornography to women.53 A content-based restriction on sexist expression would be appropriate because the harms of that speech fall almost exclusively on women. Rather than being a price we all pay, pornography makes women pay the price for expression that satisfies male sexual desire.

Having addressed direct causation of violence in the previous argument, I will focus on feminist arguments that have a more social focus. Dyzenhaus describes this approach clearly:

For procensorship feminists [violent] pornography is but one end of a continuum, the other end of which is pornography showing women consenting to and enjoying their role in satisfying male desire. These feminists think that such 'consensual' pornography is as much a matter for concern as violent pornography. ${ }^{54}$

The connection between the offensive content and social harm is the perpetuation of the idea of male power. ${ }^{55}$ Accordingly 'the harm of pornography is then the special way in which it contributes to a regime of inequality' ${ }^{56}$ This inequality manifests itself in many

51 'Consumption of material depicting non-violent sexual activity increased aggressive behaviour; and media depictions of violent sexual activity generated more aggression than those of nonviolent sexual activity.' (Itzin, Taket and Kelly, The evidence of harm to adults relating to exposure to extreme pornographic material, p. 9)

52 A recent study on violent video games notes: 'First, it appears in this study that there are effects of violent game play on aggressive outcomes. These are consistent with the claims made by social cognitive theory: mere game play can increase aggression.' (Marina Krcmar, Kristie Farrar and Rory McGloin, 'The Effects of Video Game Realism on Attention, Retention and Aggressive Outcomes', Computers in Human Behavior 27:1 (2011), pp. 432-439, at p. 438.

53 For an early version of this argument see Catherine A. MacKinnon Feminism Unmodified: Discourses on Life E Law (Cambridge, MA: Harvard University Press, 1987). More recently, see Rae Langton, 'Whose Right? Ronald Dworkin, Women, and Pornographers', Philosophy and Public Affairs 19:4 (1990), pp. 311-359.

54 See Dyzenhaus, 'Mill and the Harm of Pornography', p. 535.

55 See Andrea Dworkin, Pornography: Men Possessing Women (New York: Putnam, 1981).

56 Dyzenhaus, 'Mill and the Harm of Pornography', p. 536. 
obvious ways, like pay-gaps and glass-ceiling, and more subtle ones including 'experiences of subordination' as well increased levels of 'unease, distress, and anger'. ${ }^{57}$

These harms are significant and certainly infused into our social world in pernicious ways. Pornography is part of a general cultural tendency to sexualize women's bodies wherever they are. Nudity and sexually explicit content are not necessary in order for this to occur. This point weakens the plausibility of a genuine distinction between obscene pornography and the rest. Objectification and 'pornification' are present in almost all pornography that is created and consumed. ${ }^{58}$ The most violent forms of pornography attract the most attention, but the degradation seen there is, as Dyzenhaus notes, on a continuum with degradation seen in all non-violent pornography that depicts women in servile positions. If this is cause for censorship then it will apply to much more than is currently prohibited by obscenity law in the U.S., Canada, and the U.K. An argument for treating all hardcore pornography as obscene will not fit within existing legal frameworks.

So much the worse for those legal frameworks then. This reply leads to a second reply. The social harms under consideration pertain to the social inequality of women relative to men. This is a matter of basic justice that requires political action. However, it would be very difficult to isolate the unique contribution that obscenity makes to the social inequality of women, even if it plays a contributing role. As Brecher compellingly states,

[p]ornography does not simply mirror society: as with violence on TV or 'lonely hearts' advertisements in the press, so pornography helps create society in its image; and it does not simply give people what they want, it gets them to want those, and other, things. 59

Since my concern here is whether obscenity merits special treatment under the law, any objection that puts all pornography on a continuum will find evidence of social harm to unwilling audiences caused by any private use of pornography. This is incompatible with both a Millian principle protecting some domain of privacy in which to pursue liberty of tastes, and the legal distinction between protected and unprotected pornography.

Moreover, this is a place where regulation stands out as a viable solution that meets most of the interests at stake. If pornography is protected speech this does not mean that women (or men) must accept its presence either in public or in their private lives. As discussed, technological and regulatory solutions exist here to protect unwilling audiences. This ensures some private space for every individual where they are not answerable to the demands of society. This will not defeat the social harms of inequality. What this does is break the direct connection between pornography consumption by an individual in private and invading another's sovereign control over body and mind. The protection of privacy both legally and ethically is something every citizen can demand,

57 Julia Long, Anti-Porn: The Resurgence of Anti-Pornography Feminism (London: Zed Books, 2012), at p. 144.

58 Ibid., p. 111.

59 Brecher, Getting What You Want?, p. 157. 
and this will protect both those who want to consume obscenity and those who want freedom from it. 60

To sum up: none of the versions of the social harm argument considered will establish that there is a unique harm in the private use of obscene materials versus the private use of other sexually explicit speech or other offensive content more generally. The harms we do find are either too causally remote or too inclusive to justify the special legal treatment of obscenity. This is, I think a dead end for defending content-specific restrictions within the domain of pornography. I turn now to the different and more promising argument that obscenity involves moral harm and this differentiates it from other expression.

\section{Moral Harm}

Consider the following hypothesis: obscenity threatens to impair a person's ability to function as a normal member of society. The Harm Principle forbids laws that force us to act for our own moral perfection, but it does not categorically prohibit laws aimed at protecting the individual's long-term well-being. For example, when I engage in irrationally risky behavior that threatens my survival the Harm Principle allows legal interference as consistent with my sovereignty. Such laws are paternalistic, but the paternalism is not motivated by moralistic considerations. ${ }^{61}$ Rather, the legal intervention tries to prevent bad outcomes for me that I would recognize as bad by my own lights. ${ }^{62}$ In the moment, there is some temporary impairment to my cognitive faculties that prevents me from seeing how to achieve what I want. In such cases intervention aims to uphold what agents would, in time, regard as their own best interests. Paternalistic state intervention is for the sake of individual liberty.

This kind of legal paternalism has strong textual support in Mill. He famously argues that no society should recognize a contract to sell oneself into slavery. ${ }^{63} \mathrm{He}$ also allows that we can interfere with a person suffering from impairment with respect to 'the full use of the reflecting faculty' ${ }^{64}$ His reasoning is that the state is responsible for respecting our ability to pursue what we desire, and our power to formulate coherent desires is vulnerable. In such cases, the proper policy is not one of non-interference. As Mill says about restraining the man unknowingly walking on a faulty bridge, 'liberty consists in doing what one desires, and he does not desire to fall into the river' ${ }^{\prime}{ }^{6}$

60 This reply to pro-censorship feminist argument is not decisive. I return to these concerns in the next section.

61 This argument is different from the debate about the status of 'morality-dependent harms' in Mill's theory. The moral component of moral harm is primarily about the agent's interests rather than the audience's. For a discussion of the importance of morality dependent harms see Ted Honderich's 'On Liberty and Morality-Dependent Harm', Political Studies 30:4 (1982), pp. 504-514. For a reply, see Jeremy Waldron, 'Mill and the Value of Moral Distress', Political Studies 35:3 (1987), pp. 410-423.

62 Some argue that these kinds of laws don't even count as paternalistic. See, for example, Joel Feinberg, The Moral Limits of the Criminal Law Volume 3: Harm to Self (Oxford: Oxford University Press, 1989), pp. 12-16.

63 'It is not freedom to be allowed to alienate his freedom.' (Mill, On Liberty, p. 170)

64 Ibid.,p. 165.

65 Ibid. 
One can construct a parallel argument regarding moral harm: (1) moral harm is the likely consequence of willing exposure to obscene materials, (2) moral harm impairs normal human functioning, (3) this leads to bad consequences that the agent would regard as bad, were the agent thinking clearly. Therefore, (4) the state is warranted in restraining the person from viewing morally harmful pornography. This is a restraint that prevents an even greater evil to the agent.

If this is right, then we have a harm-based justification for restricting private consumption of obscene materials. This argument rests on what I'll call the Moral Harm Hypothesis, according to which obscene pornography is material that contains a high risk of serious impairment to a person's ability to engage in normal human relationships (sexual, social, or otherwise). ${ }^{66}$ We have a valid basis for restricting access to such materials due to the depth, gravity, and scope of the impairment for the agent. This is a harm-to-self that leads to bad consequences, mostly for the agent but also indirectly for others. A rational agent sees these outcomes as bad and would choose not to become so impaired. If obscenity can make one's life worse in ways that we can see clearly from the outside but lose track of once we are in the grip of these materials, then our dominant preference would be protection from this harm. An interference with the agent's choice of pornography is therefore compatible with the agent's independence.

This hypothesis, if confirmed, would justify the divergent opinions in Rowan and Miller and more generally provide an ethical basis for treating some pornographic depictions as worse than others. This would preserve the distinction between obscenity and pornography in a simple and plausible way. Run-of-the-mill pornography presents a low risk of damage to a person's healthy functioning. This level of risk falls within an acceptable range, akin to the risk we tolerate with other bad habits. With obscenity, the risk that significant damage will occur is much higher, given how disturbing these images are. ${ }^{67}$

This way of singling out obscenity via the concept of moral harm is a compelling alternative to the social harm strategy considered earlier. We have identified a kind of

66 This concept of moral harm differs from the one discussed by Koppelman in 'Does Obscenity Cause Moral Harm?'. For Koppelman, moral harm involves an impairment in 'B's ability to discern the morally better from the morally worse.' (p. 1643) My focus is interpersonal. I am concerned specifically with the kind of moral harm that affects our ability to stand in working relations with others. This is, arguably, a species of the category of moral harm Koppelman describes. Another conception of moral harm comes from Feinberg's The Moral Limits of the Criminal Law Volume 4: Harmless Wrongdoing (Oxford: Oxford University Press, 1990), pp. 22-23. Feinberg describes moral harm as rendered void in those cases where the agent had no antecedent interest in avoiding the harm. Thus, for Feinberg, there is no external standard against which a person's subjective preferences are to be evaluated. Like Koppelman I reject the conception of well-being that underlies Feinberg's argument that moral harms is not real harm for political purposes. Mill clearly employs an external standard of well-being when he appeals to mankind's 'progressive' interests as those which should not be setback by social policies. For an elaboration of this idea in Mill, see Brink, 'Millian Principles, Freedom Of Expression, And Hate Speech'.

67 This tracks a distinction we often draw between hard and soft drugs. On some views, the latter may be used recreationally without significant risk. However, almost everyone is exposed to significant harms (addiction, sickness, poverty, etc.) through the use of hard drugs. Recent reviews have found little supporting data for pornography addiction as a pathology. See David Ley, Nicole Prause and Peter Finn, 'The Emperor Has No Clothes: A Review of the "Pornography Addiction Model"' , Current Sexual Health Reports 6:2 (2014), pp. 94-105. 
harm that plausibly could be the consequence of viewing some but not all types of pornography. This harm has debilitating effects that any rational agent would want to avoid, and a restriction on the production and consumption of obscene pornography would leave non-obscene pornography untouched.

In order for this argument to work we need to be more precise about how we understand the purported debilitating effects of being morally harmed. How does moral harm make its way in and how does it manifest itself? One way of spelling this out is that exposure to disturbing content can dull our moral sensibilities. ${ }^{68}$ On this view, the damage done by obscenity lies in its tendency to make us into morally worse people. The trouble with this conception echoes the problem with saying that obscenity causes social harm by making people more dangerous. The evidence does not support the connection. It is very plausible that those who enjoy obscene pornography are inuring themselves to things that should fill them with revulsion, as they do for most others. However, enjoying content that should be upsetting does not make one less likely to obey the speed limit, tell the truth on the witness stand, or pay one's taxes. Further, under the Harm Principle the state is barred from coercively bringing about our moral improvement. Dulling one's moral sensibilities in a way that has no clear harmful effects on others remains in the protected sphere of personal sovereignty. Once I stop paying my taxes then the state can punish me for that. My pornography preferences have nothing to do with that. So this conception of moral harm risks quickly sliding into a form of legal moralism that is not sanctioned by Mill's ethical theory.

A second way of conceiving of moral harm is a weaker variant of the dulled sensibilities argument: obscenity warps our views about normal human relations, and so makes us less able to function within conventional social norms. This version of moral harm leaves aside moralistic considerations and focuses instead on the basic capacities we all need to get around in society. It seems initially plausible that long-term exposure to obscenity could impair a person's ability to have successful social and personal relationships. This argument is often being made with respect to Internet pornography in general. Its sheer volume and ease of access has a profound effect on how individuals see themselves and others. Regular use of pornography blurs the line between fantasy and real life. ${ }^{69}$ This blurring between fantasy and reality is present in obscene pornography as well. And if obscene pornography is deeply warping, then the risk to the individual is significant. Indeed, this is the concern voiced by the Canadian court, which sees the role of obscenity law to prevent 'degradation, humiliation, victimization, and violence in human relationships appear normal and acceptable'.70

This conception of moral harm brings conservative and liberal sides as well as pro- and anti-censorship interpreters of Mill very close together. The reason obscenity involves a moral harm is because it distorts our conception of others in a way that risks worsening our social and intimate relationships. This has nothing to do with moralistic

68 Immanuel Kant famously argued that cruelty to animals 'weakens' our moral sensibilities and facilitates a transition to moral failure towards human beings.

69 There is research linking pornography consumption to a decrease in commitment to one's primary romantic relationship. See, for example, Nathaniel M. Lambert, Sesan Negash, Tyler F. Stillman, Spencer B. Olmstead and Frank D. Fincham, 'A Love That Doesn't Last: Pornography Consumption and Weakened Commitment to One's Romantic Partner', Journal of Social and Clinical Psychology 31:4 (2012), pp. 410-438.

70 Regina v. Butler 1 S.C.R. 452 (1992), emphasis added. 
ideals of what relationships should look like. This is simply about making sure the agent is able to be in the kinds of relationships he or she wants.

In order to justify coercive interference we don't need proof of a necessary causal connection between obscene pornography and warpage. All we need is that the risk to the average person be high. ${ }^{71}$ If obscenity can cause relational debilitation in some nontrivial percentage of people, then there is no theoretical tension between empowering states to protect us from this kind of harm.

The reason this unites all camps is that there is general agreement on the value of making meaningful choices. There is a broader disagreement, of course, about what makes a choice meaningful. However, all can agree that protecting people from debilitating consequences of their mistakes has some place within the law. This will justify coercive protection for the sake of the individual when things are dire.

This also provides the state with a legitimate, albeit indirect, interest in the character of its citizens. As citizens we are often required to stand in good social relations with others. We have responsibilities to pay taxes and drive safely in traffic, to raise our children well and to take care of our elderly family members and to act decently towards our neighbours. Relational impairment is for that reason not a purely private outcome. If moral harm damages these social capacities, then agents will be less able to function in the ways expected of citizens. Therefore, even our most personal private relationships spouses, parents, children, intimates - have a public dimension.

We have now identified and clarified a kind of privately induced self-harm that falls within the state's legitimate concern. ${ }^{72}$ This conception of moral harm passes both parts of Mill's principle and fits well with his discussion of self-harmful consumption habits in On Liberty. We now have an ethical basis for the law of obscenity. Could a concern for moral harm vindicate the distinction between pornography and obscenity drawn by the U.S. Supreme Court in Miller?

There are several reasons why this cannot be the case. First, recall that Miller stipulates that obscenity must involve appeal to a 'prurient interest' in sex. Under Miller, if it's not sexual in nature it cannot be obscene. According to the current view of moral harm this restriction is unwarranted. Gory movies, violent video games, and sadistic song lyrics can all be morally harmful to some audiences. If our concern centres on relational impairment then violence without sex needs to be on the list of what counts as obscene. ${ }^{73}$ Further, many common forms of popular entertainment also have the potential to warp our views about how normal people behave. In the case of sitcoms and reality TV the risks of warping are high precisely because the moral harm they contain hides in plain sight.

This is not a knockdown point against the moral harm hypothesis, but only an argument that the actual verdict in Miller cannot be understood as appealing to this broad conception of moral harm. Miller is too narrowly drawn to be relying on a general

${ }^{71}$ In discussing whether poisons should be freely available Mill acknowledges that failure to warn via labeling about this risk constitutes harm because ' $[\ldots]$ the buyer cannot wish not to know that the thing he possesses has poisonous qualities.' (Mill, On Liberty, p. 165)

72 This is in line with Mill's argument that drunkenness may well be private but that failure to take care of one's children because one is drunk is not. In such cases, the law may be used to curb excessive drinking. (Mill, On Liberty, p. 166)

73 The same argument could be made about hateful materials. See Sumner, The Hateful $\mathcal{E}$ The Obscene, Ch. 3. 
concern for relational impairment. Miller could obviously be expanded to include nonsexual expression.

A second problem with understanding Miller as focused on moral harm is that this would end up collapsing the distinction between pornography and obscenity. If we truly believe that sexual materials contain a high risk of distortion leading to impairment, then the charge would stick against almost all commercial pornography. Most of it is fantastical and larger than life, and most of it paints a deeply inegalitarian picture of gender roles. So the attempt to isolate obscene pornography on the basis of its harmful content would fail.

Accordingly, all pornography would be suspect. Once all pornography is capable of being censored then the distinction between obscenity and pornography would depend on establishing a threshold risk for warping messages. ${ }^{74}$ However, Miller's blunt way of approaching these subtle differences of degree is by reference to the views of the community as a whole. The threshold is to be drawn by the community's standards of offense at prurient displays of sex..$^{75}$ This route leaves behind concerns about moral harm in the sense of impairment. In its place we give legal force to the moral disapproval of the community of certain sexual preferences. For Mill, this is precisely the tyranny from which citizens need protection. As I have argued, the only way to vindicate the legal difference between pornography (Rowan) and obscenity (Miller) is to show that there are harms in the latter but not the former. The community standards approach doesn't uncover this harm; it merely reports the point at which the average person is offended by sexually explicit content.

This leads to a final point. Appealing to moral harm to ban sexual expression requires demonstrating that the harm in question interferes with the minimal conditions necessary for an agent to stand in functional relations with others. That is what, on the moral harm hypothesis, converts the matter from being private into being public. Obscenity might contribute to making you a less good human being, but we have no strong empirical case for thinking that it incapacitates your basic social functioning. And this is what we would need to show - that the choice to consume obscenity is like the choice to use damaging drugs. No rational person would choose the physical, economic, and social hardships associated with addiction to hard drugs, were the person to know in advance that these evils would ensue. Laws against hard drugs make sense precisely because the causal connection between consumption and the likelihood of harmful addiction is demonstrably strong. There is no similar evidence about consumption of obscenity. Rather, some studies show that pornography can have beneficial social and personal effects for some agents. ${ }^{76}$

The evidentiary burden that falls to the defender of moral harm is the following. First one must show that obscene pornography is a significant cause of harmful warping,

74 This is, I think, the best way to conceptualize the difference between pornography and obscenity. I'll return to this in the next section.

75 Despite statistics on the widespread use of pornography, public opinion of pornography is quite low. Recent studies put pornography usage among young men around 87 per cent and young women around 31 per cent. See Jason S. Carroll, Laura M. Padilla-Walker, Larry J. Nelson, Chad D. Olson, Carolyn McNamara Barry," Stephanie D. Madsen, 'Generation XXX: Pornography Acceptance and Use among Emerging Adults', Journal of Adolescent Research 23:1 (2008), pp. 6-30.

76 See Mary Anne Watson, Randyl D. Smith, 'Positive Porn: Educational, Medical, and Clinical Uses', American Journal of Sexuality Education 7:2 (2012), pp. 122-145. 
as opposed to simply having one's horizons expanded. Then, one must show that these warping effects are socially debilitating to a higher degree than other offensive content. This step provides the basis for coercive interference in the name of the agent's own rational interests. Both points point require empirical findings in order to overturn the Millian presumption in favour of non-interference, especially in matters concerning the basic rights to both freedom of expression and to liberty of tastes and pursuits. Absent this evidence, an argument for obscenity law based in moral harm is at best a wellmeaning form of paternalistic over-reaching, and at worst straightforward legal moralism.

In sum, neither an other-regarding argument from social harm nor a selfregarding argument from moral harm provides a justification for the legal practice of treating obscenity as low value. Obscenity should not be exempted from the usual protections against content-based restrictions. Expression that is vapid, racist, homophobic, sexist, gory, or hateful is entitled to protection under the First Amendment. For reasons of consistency, obscenity belongs in this group as well.

\section{Conclusion: Beyond the Harm Principle}

Recall the list of unprotected low-value speech: obscenity, defamation with malice, false or misleading commercial advertising, fraudulent solicitation, incitement to lawbreaking, and threats of violence. When juxtaposed with threats and fraud, obscenity is out of place. In each of the other examples I threaten or succeed in taking something away from another. And indeed, if I were to do so I would likely create a harm. But the harm is not what makes these actions wrong. Rather, the wrong is that I am depriving another of something that is not mine to control. Fraud deprives you of your money, defamation deprives you of the ability to enter into arrangements with others based on your actual track-record, and the riot I cause deprives you of your physical safety. There are often harms associated with these wrongs, but there need not be. I could defraud you in a way that leads to your benefit, or I could engage in deceptive advertising to get you to act in your own best interests. These are still wrongs because I take something of yours without your consent. We don't need to look for harm to establish that these actions invade your sovereignty.

Framed in this way, it is clear that obscenity law doesn't belong here. ${ }^{77} \mathrm{My}$ private use of obscene materials does not deprive anyone else of anything that is theirs to control. Attempts to lump the speech-based harm of obscenity with the speech-based harm of fraud is conceptually confused. This is a failure in the Court's reasoning in Miller, but it is a failure that is invited by the Harm Principle. As noted, it is compatible with Mill's argument to show that a harm-to-self is so severe that it results in harm-to-others. And this bolsters the idea that obscenity is like fraud in that both eventually lead to harm others.

However if obscenity threatens harm to others it does so in a way that is wholly unlike the threat contained in fraud or inciting riots. Those actions involve individual

77 For an argument that pornography is like low-value fighting words see John M. Kang's 'Taking Safety Seriously: Using Liberalism To Fight Pornography', Michigan Journal of Gender E Law 15:1 (2008), pp. 1-40, at pp. 10-11. 
interpersonal domination: taking away your independence and putting mine in its place. No such thing happens when I willingly expose myself to obscenity. It may be the case that moral self-harm will eventually have negative spillover effects on the rest of my life, and on society. When that happens the problem lies very far from the obscene expression. This is more like Mill's example of publishing a column about the tyranny of the corn dealers. Any incitement this brings about will go through the agent's will. The speech is part of the causal story but not in any unique way.

However, in light of the analysis given here, it would be a mistake to see no possible relation between the harm in fraudulently deceptive advertising and the harm in obscenity. As I have argued, if moral harm is real harm, then Mill's principle needs to countenance it, even if this harm will not on balance justify a legal prohibition.

The need to acknowledge and compare harms beyond physical harms is a strength and a weakness of Mill's principle. It's a strength because it forces us to consider the severity of different kinds of harms as well the extent of their effects. Differences of degree should matter when determining if the law ought to be used or if regulation would suffice. This sensitivity to the degree of harmfulness becomes a weakness when applied to the case of obscenity. Under the Harm Principle, whether or not a harm is private in the right way is not up to you to decide. This blurring of the line between public and private is what makes Miller problematic, as well as the UK's inclusion of disgust and offense in the CJIA and the Criminal Justice and Court Bill Act. ${ }^{78}$ You think there is nothing wrong with consuming privately your preferred kind of pornography but as it turns out the community gets to deny this choice, based on what most people would regard as disgusting and deeply disturbing.

My argument is that individuals should be able to block intrusion into their pornography preferences simply by asking 'who am I wronging by watching legally created extreme pornography made by consenting adults in the privacy of my own home?' No one has a right invade the sovereignty of others over their own body and mind. The government may not invade my right to liberty of tastes unless it can connect my actions with assignable wrongful harms. It cannot.

My conclusion is that the law of obscenity as presented in Miller, Butler, and the OPA is unjustified on both ethical and empirical grounds. Obscenity law involves the state in a paternalistic form of content-based censorship. As a matter of policy, whatever harm are contained in obscenity can be dealt with by regulatory measures like zoning laws, permits, workplace safety standards, and restrictions on selling to minors. These restrictions are appropriate for obscenity just as they are appropriate for pornography and gore. There is no reason, however, to restrict the production, sale, or possession of obscenity to consenting adults assuming that all parties depicted gave initial and ongoing consent. Regulatory determinations based on what people find disgusting or depraved are incompatible with independence.

The moral harm hypothesis fails to justify current legal practices, but it also points to a different and promising way of thinking about what to do with the worst kind of pornography. We should abandon the distinction between obscenity and pornography

78 Criminal Justice and Courts Bill - Extension of the offence of Extreme Pornography (possession of pornographic images of rape and assault by penetration). Online at https://www.gov.uk/government/uploads/system/uploads/attachment_data/file/322160/factsheet-extreme-porn.pdf (accessed 2017-05-04). 
altogether and replace it with the distinction between safe and risky pornography. This terminology highlights the harm we are trying to mitigate by involving the law within the domain of regulating content. The most common risks of pornography use are relational. The risk is that a person will not be able to separate what they see on screen with what they want out of their relationships. Pornography creates expectations that individuals carry over into their bedrooms at beyond.

Here are two concrete examples. First, some of the expectations people acquire from pornography can harm partners performing sexual acts that can only be done safely by experienced professionals, sometimes with expensive specialized equipment. This is a clear place where some pornography is riskier than others to its audience, and so deserves stricter regulation.79 Second, some pornography can negatively affect relationships by making extreme sexual acts that are not necessarily painful or physically harmful seem conventional. Here I am thinking of cases involving physical restraint, humiliation, role-play, and other vulnerability-inducing acts or contexts. A partner whose appetite for these extreme acts is (understandably) low may be pressured to regard these acts as basic, in light of the partner's exclusive interest in this kind of pornography.

No rational agent wants to be burdened by having sexual expectations that will physically harm their partners or lead to being perpetually dissatisfied with one's partner. This is a kind of self-regarding harm we can all acknowledge as contrary to our interests in having successful relationships. Stricter regulation of physically and emotionally risky pornography is compatible with (and arguably required by) a Millian framework. This regulatory approach is also compatible with pursuing gender equality, although in a way that will seem inadequate for pro-censorship feminists. Mill was adamant that censorship robs us of an opportunity to exchange falsity for truth and to see truths enlivened by striking down falsehoods. One of the important discussions to have and to have more publicly is why so many men enjoy seeing women in servile positions, beaten, or brutalized. This desire rests on a falsehood about women and their place relative to men. The criminalization of pornography that feeds these desire distorts the marketplace by adding to its appeal. In order to see that falsehood replaced with truth, much more needs to be understood about these desires and their source. Obscenity law interferes with this goal. ${ }^{80}$

Michael Joel Kessler, University of Toronto mkessler@trinity.utoronto.ca

\footnotetext{
79 This is compatible with criminal or civil sanctions resulting from harming another through risky sexual practices.

80 Versions of this paper have been presented to the Toronto Area Political Philosophy group, the Bechtel Workshop in Moral \& Political Philosophy, and New Research in Practical Philosophy. I thank participants at these meetings, especially Laurens van Apeldoorn. I also thank the anonymous reviewers from De Ethica for immensely helpful comments.
} 


\section{Bibliography}

Boyce, Bret. 'Obscenity and Community Standards', Yale Journal of International Law 33 (2008), pp. 299-513.

Brink, David. 'Millian Principles, Freedom Of Expression, And Hate Speech', Legal Theory 7 (2001), pp. 119-157.

Brecher, Bob. Getting What You Want? A Critique of Liberal Morality. London: Routledge, 1998.

Carroll, Jason S.; Laura M. Padilla-Walker, Larry J. Nelson,; Chad D. Olson; Carolyn McNamara Barry, and Stephanie D. Madsen. 'Generation XXX: Pornography Acceptance and Use among Emerging Adults', Journal of Adolescent Research 23:1, 2008), pp. 6-30.

Criminal Justice and Immigration Act

Criminal Justice and Courts Bill - Extension of the offence of Extreme Pornography. Online at: https://www.gov.uk/government/uploads/system/uploads/ attachment_data/file/322160/fact-sheet-extreme-porn.pdf (accessed 2017-05-04).

Diamond, Milton. 'Pornography, Public Acceptance and Sex Related Crime: A Review', International Journal of Law and Psychiatry 32 (2009), pp. 304-314.

Dworkin, Andrea. Pornography: Men Possessing Women. New York: Putnam, 1981.

Dyzenhaus, David. 'Mill and the Harm of Pornography', Ethics 103:3 (1992), pp. 534-551.

Feinberg, Joel. The Moral Limits of the Criminal Law Volume 3: Harm to Self. Oxford: Oxford University Press, 1989.

Feinberg, Joel. The Moral Limits of the Criminal Law Volume 4: Harmless Wrongdoing. Oxford: Oxford University Press, 1990.

Honderich, Ted. 'On Liberty and Morality-Dependent Harm', Political Studies, 30:4 (1982), pp. 504-514.

Itzin, Catherine, Ann R. Taket and Liz Kelly. The Evidence of Harm to Adults Relating to Exposure to Extreme Pornographic Material: A Rapid Evidence Assessment. Ministry of Justice research series, 11/07 (London: Ministry of Justice, 2007).

Jochelson, Richard, 'After Labaye: The Harm Test Of Obscenity, The New Judicial Vacuum, And The Relevance Of Familiar Voices, Alberta Law Review. $46: 3$ (2009), pp. 741-767.

Johnson, Paul. 'Law, Morality and Disgust: The Regulation of "Extreme Pornography" in England and Wales', Social \& Legal Studies 19:2 (2010), pp. 147-163.

Kang, John M. 'Taking Safety Seriously: Using Liberalism To Fight Pornography', Michigan Journal of Gender \& Law 15:1 (2008), pp. 1-40.

Koppelman, Andrew. 'Does Obscenity Cause Moral Harm?', Columbia Law Review 105:5 (2005), pp. 1635-1679.

Krcmar, Marina, Kristie Farrar and Rory McGloin. 'The Effects of Video Game Realism on Attention, Retention and Aggressive Outcomes', Computers in Human Behavior 27:1 (2011), pp. 432-439.

Lambert, Nathaniel M., Sesan Negash, Tyler F. Stillman, Spencer B. Olmstead and Frank D. Fincham. 'A Love That Doesn't Last: Pornography Consumption and Weakened Commitment to One's Romantic Partner', Journal of Social and Clinical Psychology 31:4 (2012), pp. 410-438.

Langton, Rae. 'Whose Right? Ronald Dworkin, Women, and Pornographers', Philosophy and Public Affairs 19:4 (1990), pp. 311-359. 
Ley, David, Nicole Prause and Peter Finn. 'The Emperor Has No Clothes: A Review of the "Pornography Addiction" Model', Current Sexual Health Reports 6:2 (2014), pp. 94105.

Long, Julia. Anti-Porn: The Resurgence of Anti-Pornography Feminism. London: Zed Books, 2012.

MacKinnon, Catherine A. Feminism Unmodified: Discourses on Life \& Law. Cambridge, MA: Harvard University Press, 1987.

Mill, John Stuart. 'On the Subjugation of Women' (1869), in On Liberty and Subjection of Women, edited by Alan Ryan. London: Penguin Classics, 2006.

Mill, John Stuart. On Liberty (1859), edited by Mary Warnock. Oxford: Blackwell: 2003.

McGlynn, Clare, and Erica Rackley. 'Criminalising Extreme Pornography: A Lost Opportunity', Criminal Law Review 4 (2009), pp. 245-260.

McGlynn, Clare, and Ian Ward. 'Would John Stuart Mill have Regulated Pornography?', Journal Of Law And Society 41:4 (2014), pp. 500-522.

Obscene Publications Act

Rackley, Erika, and Clare McGlynn. 'Prosecuting the Possession of Extreme Pornography: A Misunderstood and Misused Law', Criminal Law Review 5 (2013), pp. 400-405.

Scanlon, Thomas M. 'Freedom of Expression and Categories of Expression', University of Pittsburgh Law Review 40 (1978-1979).

Stone, Geoffrey R. 'Restrictions of Speech Because of its Content: The Peculiar Case of Subject-Matter restrictions', The University of Chicago Law Review 46:1 (1978), pp. 81115.

Sumner, Leonard W. The Hateful \& The Obscene. Toronto: University of Toronto Press, 2004.

Waldron, Jeremy 'Mill and the Value of Moral Distress', Political Studies 35:3 (1987), pp. $410-423$

Watson, Mary Anne, and Randyl D. Smith. 'Positive Porn: Educational, Medical, and Clinical Uses', American Journal of Sexuality Education 7:2 (2012), pp. 122-145. 